30a IV 4

(招待講演)
SHG 青紫色レーザーと、その高密度光ディスク応用

SHG Blue-violet Laser and its Application to High-density Optical Disk Systems

○北岡康夫、鳴海建治、水内公典、山本和久、横山敏史、加藤誠、杉田知也 (松下電器産業侏) 光ディスク開発センター)

${ }^{\circ}$ Y.Kitaoka, K.Narumi, K.Mizuuchi, K.Yamamoto, T.Yokoyama, M.Kato and T.Sugita (Matsushita Electric Industrial Co., Ltd.)

1. はじめに

近年、情報化社会が著しい発展を遂げる中、半導体メモリ、ハードディスク、フロッピディスクおよび光ディスクなどの記録メディアの大容量化/ 高速化にはめざましいものがある。光ディスクシステムにおいては、赤色半導体レーザーを用いた記録再生可能な DVD システム(容量 4.7GB) が登場し、現行放送 (NTSC 方式)を約 2 時間記録することが可能なディジタルビデオディスクレコーダも製品化された。今後、さらに映像の高緎 細化が進み情報も大容量化すると、さらなる高密度化が必要とされる。

光ディスクの高密度化技術として、光源の短波長化 $(400 \sim 415 \mathrm{nn})$ 技術 ${ }^{1,2)}$ や集光レンズの高開口数(NA)化技術 ${ }^{3)}$ が有望視されていて、これ らの技術を組み合わせることにより、15 30GB の大容量記録再生システムが実現できる。光ディスク用光源には、低ノイズ $(-135 \mathrm{~dB} / \mathrm{Hz}) 、$ 高出 力 $(>20 \mathrm{~mW})$ 、高速変調 $(\sim 50 \mathrm{MHz})$ 、高集光特性などが要求される。我々は、2次の非線形光学効果を利用した第 2 高調波発生 (SHG:Second Harmonic Generation)に注目している。レーザー光の波長を半分の波長に変換できるため、基本波として近赤外領域の半導体 レーザー $(800 \sim 860 \mathrm{~nm})$ を用いることにより、青紫色領域 $(400 \sim 430 \mathrm{~nm})$ の光を得ることができる。中でも、周期的分極反転構造とプロトン交換光 導波路から構成される光導波路型擬似位相整合方式(QPM:Quasi-Phase-Matched)-SHG デバイスは、大きな非線形係数 $\left(\mathrm{d}_{33}\right)$ の利用、長い 相互作用長などにより高効率波長変換が期待できる4)。

今回、波長可変分布ブラッグ反射型(DBR:Distributed Bragg Reflector)半導体レーザーと光導波路型 QPM-SHG デバイスをSi サブマウント 上に実装したプレーナ型超小型 SHG 青色レーザー $(426 \mathrm{~nm})$ を提案し、 $20 \mathrm{~mW}$ 以上の青色パルス光を発生した。また、光ディスク応用について 検討を行った。さらに、オフカット基板へのマルチショートパルス印加により分極反転の短周期化に成功し、高出力青紫光 $(392 \mathrm{~nm})$ 発生を実現し たので報告する。

2. SHG 青色レーザーの構成

図 1に、プレーナ型超小型 SHG 青色レーザーの構成を示す5)。Siサブマウント上に、波長可変 DBR 半導体レーザーと光導波路型 QPM-SHG デバイスが実装されている。波長可変 DBR 半導体レーザーは、活性領域とDBR 領域から構成されており、出力 $80 \mathrm{~mW} 、$ 発振波長 $852 \mathrm{~nm}$ であ る。発振波長は DBR 領域からの㷌還光により制御されていて、DBR 領域に電流注入することにより $2 \mathrm{~nm}$ 可変することができる。一方、光導波路 型 QPM-SHG デバイスは、xカット $\mathrm{MgO}: \mathrm{LiNbO}_{3}$ 基板上に擬似的な位相整合を満足させるための周期的分極反転領域と、低損失なプロトン交 換光導波路から構成される。xカット $\mathrm{MgO}: \mathrm{LiNbO}_{3}$ 結晶は、青紫色領域においても大きな耐光損傷性を有し、高出力発生に有利な基板材料で ある。周期的分極反転領域は、十面に作製した櫛形電極とストライプ電極の間に電界を印加することで形成した。分極反転領域の周期は、 $3.2 \mu \mathrm{m}$ である。

実装方法について説明する。半導体レーザーおよび SHG デバイスは、活性層側( $\mathrm{P}$ 側)および光導波路面 (十x面)がサブマウントに接するよ うに実装した。活性層と光導波路の高さは、 $\mathrm{SHG}$ デバイス上の $\mathrm{SiO}_{2}$ 膜の厚みで調整されている。半導体レーザーの出射端面と $\mathrm{SHG}$ デバイスの 入射端面を $3 \mu \mathrm{m}$ 以下に調整し、半導体レーザ一を発光させた状態で、SHG デバイスを光軸に対して横方向 (矢印の方向)に調整し、光導波 路の出射端面から得られる光出力が最大になる位置で固定した。SHG デバイスは紫外線硬化剂により固定した。図2にモジュールの外観図を 示す。結合効率 $54 \%$ を実現し、 $43 \mathrm{~mW}$ の基本波結合出力に対して、8.7mW の青色光 $(426 \mathrm{~nm}$ )を得た。また、変調特性を覦討したところ、98mW の基本波結合ピーク出力に対して $21.5 \mathrm{~mW}$ の青色パルス光を得た。

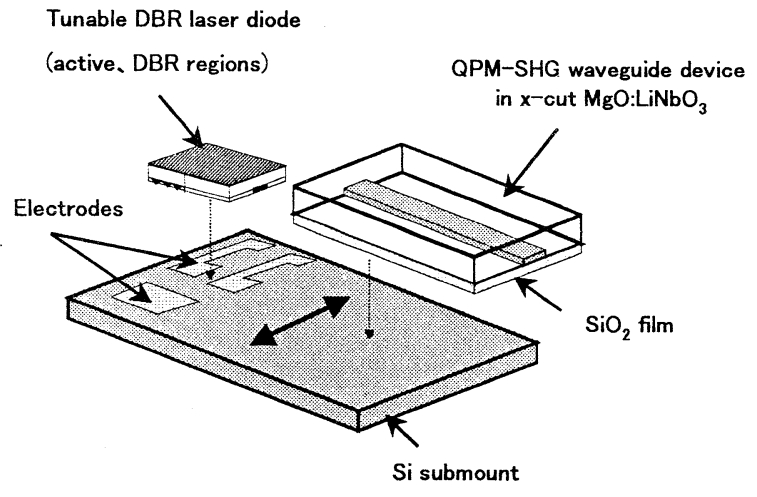

図1 プレーナ型SHGレーザーの構成

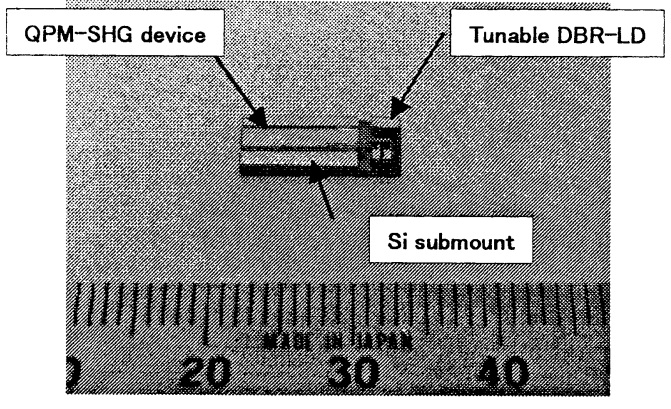

図2 プレーナ型SHG青色レーザー 
プレーナ型超小型 SHG 青色レーザーのモジュール温度変化に対する 安定性を検討した。図3に、プレーナ型直接結合モジュールの温度変化 に対する結合安定性を示す。実線はプレーナ型直接結合モジュールの 結合効率、点線は通常のレンズ結合モジュールの結合効率を示す。レン ズ結合モジュールでは、 $\pm 10^{\circ} \mathrm{C}$ のジュール温度変化に対して、30\%程度 の結合効率変化を生じた。一方、プレーナ型直接結合モジュールでは、 $10 \sim 60^{\circ} \mathrm{C}$ のジュール温度変化においても一定の結合効率を実現する ことができた。さらに、温度サイクル試験 $\left(10 \rightarrow 60 \rightarrow 10^{\circ} \mathrm{C}\right)$ での結合効率の 安定性を評価したところ、200 サイクル後においても結合効率の変化は観 測されなかった。

以上のように、結合レンズを用いないプレーナ型超小型 SHG 青色レー ザーは、モジュールの小型化を実現できるだけでなく、モジュール温度変化 に対しても結合効率を一定に保持できることが示された。

\section{3. 短波長化}

次に、波長 $400 \mathrm{~nm}$ 前後の柴色光発生について検討した。光導波路型 QPM-SHG デバイスは、分極反転周期を変化させることにより、任意 の波長に対する位相整合条件を满足できる特長を有する。しかしながら、従来の反転方法では分極反転周期を短周期化すると、反転の深さが 浅くなるため、導波モードとのオーバーラップを十分に得ることができず、高効率波長変換が実現できなかった。我々は、オフカット基板にマルチ ショートパルスを印加する新しい反転方法を提案する ${ }^{6,7)}$ 。

図4を用いて新しい反転方法について説明する。 3 度 $+\mathrm{X}$ カット $5 \mathrm{molMg}$ ドープ $\mathrm{LiNbO}_{3}$ 基板の+X 面に櫛形電極とストライプ電極を形成し、一 $\mathrm{X}$ 面に裹面電極を形成した。櫛形電極とストライプ電極の間隔は $400 \mu \mathrm{m}$ と、 $\mathrm{Ta}$ 電極の厚みは $60 \mathrm{~nm}$ である。 $+\mathrm{X}$ 面の電極表面は $\mathrm{SiO}_{2}$ 膜で覆 い、電極指間のセパレーションを向上させ、分極反転の横方向広がりを抑制した。また、分極反転の横方向広がりの原因として、ポーリング電流 による熱効果がある。熱効果による分極反転横方向広がりを抑制するため、電極にマルチショートパルスを印加した。パルス幅 $5 \mathrm{msec}$ で $5 \mathrm{kV}$ の 電生を 5 秒間隔で 5 回印加した。周期 $2.3 \mu \mathrm{m}$ の分極反転領域を図 5 に示す。反転樑さ $1.5 \mu \mathrm{m}$ 実現し、導波モードと反転領域のオーバー ラップを十分に得ることができ、高効率波長変換が期待できた。

マルチショートパルス法により得られた分極反転領域を有する基板上にプロトン交換光導波路を形成し、光導波路型 QPM-SHG デバイスを 作製して、波長変換特性を評価した。基本波としては、広い範囲で波長可変が可能な $\mathrm{Ti}_{\mathrm{i}} \mathrm{Al}_{2} \mathrm{O}_{3}$ レーザーを用いた。周期 $2.2 \sim 3.2 \mu \mathrm{m}$ 、すわな ち SHG 光の波長 392 426nm に対して、30\%/50mW の高い変換効率が得られた。図6に発振波長の安定化に狭帯域バンドパスフィルタが用 いられた半導体レーザー $(100 \mathrm{~mW})$ を基本波とした実験では、 $57 \mathrm{~mW} の$ 基本波結合出力に対して、 $17 \mathrm{~mW}$ の紫色光(413nm)を得、変換効率 $30 \%$ を実現した。基本波のピーク出力を $120 \mathrm{~mW}$ にすることで、 $20 \mathrm{~mW}$ 以上の紫色光を期待でき、記録再生可能な光ディスクへの応用可能性が示さ れた。

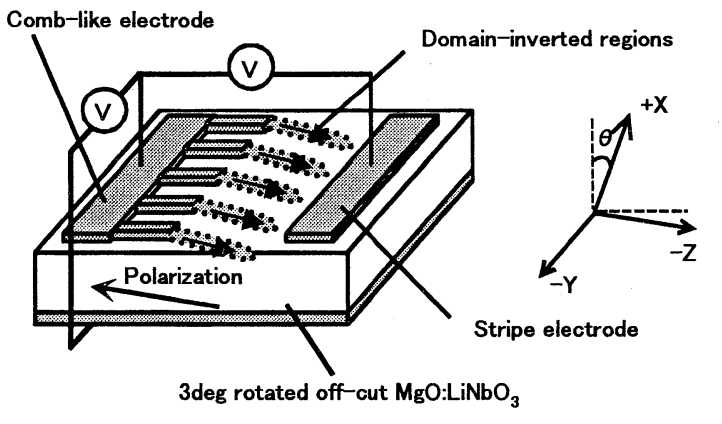

図4 周期的分極反転の形成方法

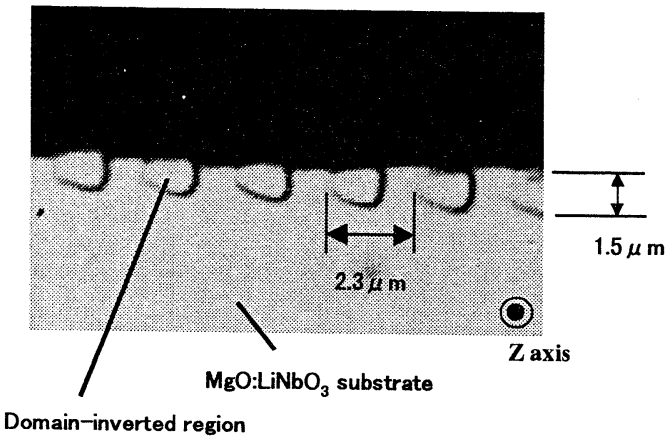

図5 周期的分極反転の断面図

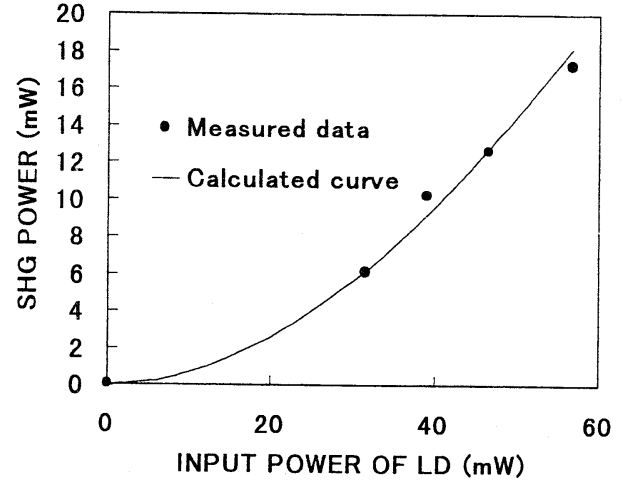

図6 光導波路型QPM-SHGデバイスの波長変換特性 


\section{4. 光ディスク応用}

SHG 青色レーザーを用いた高密度光ディスクの検討を行った。SHG 青色レ ーザー $(426 \mathrm{~nm})$ を搭載した光ピックアップは、対物レンズ後の青色出力として、 連続光で $3 \mathrm{~mW}$ 、変調ピーク出力として $9 \mathrm{~mW}$ であった。NA (開口数) $=0.6$ の 対物レンズにより、半值全幅 $0.39 \mu \mathrm{m}$ の回折限界の集光スポットが得られた。 はじめに、DVDと同じ $12 \mathrm{~cm}$ 径、厚み $0.6 \mathrm{~mm}$ の基板にランダム信号を記録 された ROM ディスクを再生した。最短ピット長が $0.26 \mu \mathrm{m}$ (DVDでは $0.4 \mu \mathrm{m}$ ) のランダム信号を再生したときのアイパターンを図7に示す。再生ジッタ $6.8 \%$ (data to clock) が得られた。

また、相変化光ディスクへの記録再生実験の橫討も行った。光ディスク基板 には DVDと同じ $0.6 \mathrm{~mm}$ 厚のボりカーボネート基榴が用いられ、基板上には スペース間隔が $0.35 \mu \mathrm{m}$ のンド・ダルーブが形成された。また、基板上に

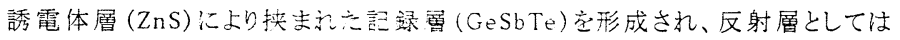

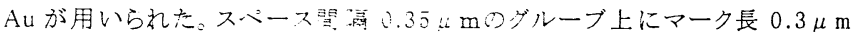

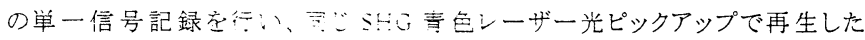

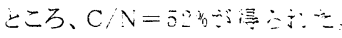

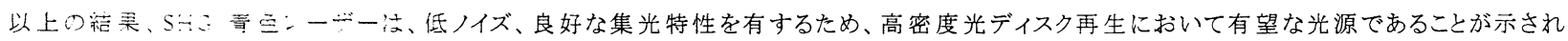

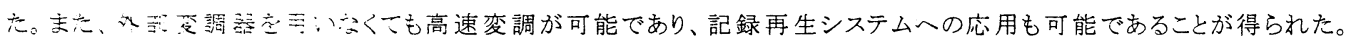

\section{5. 察}

SHG青皇, 美弁レーザーとGaN半導体レーザーの特性を表 1 に示す。SHG ンーザー洂、基本波として近赤外域のAlGaAs系半導体レーザーを用いている 亡内、2V以下の低動作電圧で駆動することができる。そのため、光ディスクの 制衘回路系い用いられているICの動作電圧と同レベルであり、回路系を簡 素化できる。一方、GaNレーザーでは、バンドギャップが大きいため、動作電圧 としては $5 \mathrm{~V}$ 程度である。また、出射ビームの横モードのアスペクト比もGaNレー ザーよりも小さく 2 以下であり、将来的には 1 に近づけることができる。これにより、 光ピックアップの光利用効率を大きくできる。さらに、基本波としてDBR半導体 レーザーを用いているため、相対雑音強度 $-145 \mathrm{~dB} / \mathrm{Hz}$ の低ノイズを実現でき、 高いデータ転送レートが期待できる。波長変換された高調波光が光ディスク に集光されるため、光ディスクからの反射青柴光が半導体レーザーに帰還して も、ノイズの劣化が生じないため高周波モジュールを必要としない。発振波長が DBRグレーティングにより制御されているため作製ばらつきも小さく、対物レンズ などの光学部品の色収差も低減できる特長も有する。

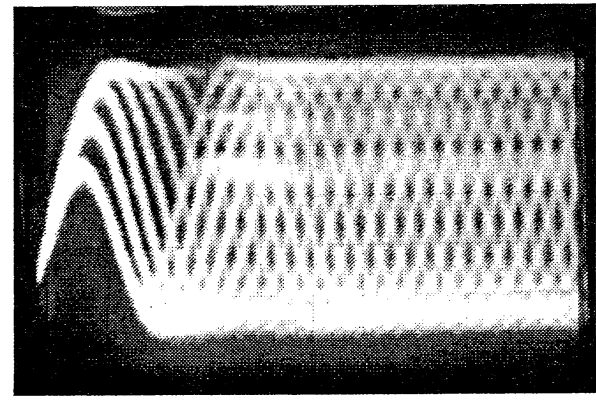

図7 SHG青色レーザーによる高密度光ディスクの再生特性 SHGレーザーは、以上のような優れた特性を有するこため、光ディスク用光源 として有望である。

\section{6. おわりに}

青色/紫色レーザーは、高密度光ディスクシステムを実現するために必要不可欠なキーデバイスであり、中でも第 2 高調波を利用した SHG 青 色/紫色レーザーは有望なアプローチである。SHG レーザーの課題であった小型化が、プレーナ型 SHG レーザーの実現により解決され、また 短周期の分極反転形成方法を確立することで紫色光発生も可能となった。

今後は、SHG 青色/紫色レーザーを用いた高密度光ディスクシステムの早期実現と、SHG 紫外レーザーの開発によるさらなる高密度化 (390nm 以下)、SHG 可視レーザー (450〜 $550 \mathrm{~nm})$ を用いた高精細プリンタやレーザーディスプレイの開発など、多方面での応用が期待される。

参考文献

1) Y. Kitaoka, K. Narumi, K. Mizuuchi, K. Yamamoto, T. Yokoyama and M. Kato: Rev. Laser Eng. 26 (1998) 256.

2) S. Nakamura: IEEE J. Quantum Electron. 4 (1998) 483.

3) K. Osato, K. Yamamoto, I. Ichimura, F. Maeda and Y. Kasami: Proc. Int. Symp. Optical Memory WA2-1 (1998) 131.

4) K. Mizuuchi and K. Yamamoto: Appl. Phys. Lett. 66 (1995) 2943.

5) Y. Kitaoka, T. Yokoyama, K. Mizuuchi and K. Yamamoto: Jpn. J. Appl. Phys. 39 (2000) 3416.

6) T. Sugita, K. Mizuuchi, Y. Kitaoka and K. Yamamoto: Rev. Laser Eng. 28 (2000) 604.

7) Y. Kitaoka, T. Yokoyama, T. Sugita, K. Mizuuchi and K. Yamamoto: Proc. Int. Symp. Optical Memory Th-H-07 (2000) 90. 